\title{
Life History of the Piked Dogfish (Squalus acanthias L.) in Swedish Waters
}

\author{
Charlott Stenberg ${ }^{1}$ \\ Fiskeriverkets Utredningskontor, Box 423 \\ SE-401 26 Göteborg, Sweden \\ Stenberg, C. 2005. Life History of the Piked Dogfish (Squalus acanthias L.) in Swedish Waters. \\ J. Northw. Atl. Fish. Sci., 35: 155-164. doi:10.2960/J.v35.m525
}

\begin{abstract}
A study of existing literature regarding the piked dogfish (Squalus acanthias) behaviour, sexual maturation and age analyses with comparison between the Atlantic Ocean and the Pacific Ocean is presented. This study examines the life history of the piked dogfish in Swedish waters. Females of the piked dogfish from the Skagerrak were investigated on two occasions during the autumn of 1997. Fifty percent $(50 \%)$ of the females were sexually mature by the age of $12-13$ years and $77 \mathrm{~cm}$. The average number of large eggs $(>2 \mathrm{~cm})$ was 8.1 and the average number of embryos was 5.8.
\end{abstract}

Key words: Atlantic, dogfish, life history, maturation, migrations, Pacific, Sweden, tagging

\section{Introduction}

The piked, or spiny, dogfish, Squalus acanthias, is a common shark in the Atlantic, the Pacific Ocean and in the Black Sea (Jones and Geen, 1976; Polat and Gümüs, 1995). Jones and Geen (1976) studied whether the piked dogfish in the Pacific Ocean should be classified as a species of its own, Squalus suckleyi, as it has been in other studies, or if it is in fact the same species in both the Atlantic and the Pacific Ocean. After electrophoretic analyses of muscle tissue and blood, comparing morphometric ratios and the number of vertebra on sharks from North America's east and west coasts, their conclusion was that the differences between the populations were not big enough to classify the population of the Pacific Ocean as a subspecies of the piked dogfish from the Atlantic Ocean. On the other hand many researchers write about the possibility of physiological differences or differences in the metabolic rate that can exist between the sharks in the different oceans. Ketchen (1975) wrote that it seems as if the piked dogfish in the Atlantic Ocean have a more rapid initial growth, become sexually mature earlier and do not attain the same size as its relatives in the Pacific Ocean. Most probably they do not reach the same age either. Something that does not seem to differ between the piked dogfish in the Atlantic and the Pacific Ocean is that it takes between 20 and 23 months for the embryos to develop after fertilization (Holden and Meadows, 1964; Jones and Geen, 1977b). On the other hand Kirnosova (1989) maintains that the piked dogfish in the Black Sea only needs 12 months for the same process.

This study examines the life history of the piked dogfish in Swedish waters.

\section{Migration}

That the piked dogfish is a migrating species can be confirmed both by fishermen and through tagging studies. Along the Swedish west coast, the main fishery for piked dogfish takes place between August and December, since they disappear after that from the area where it is possible to fish them. Also during the autumn the catch can be very variable from day to day since the fish constantly move (Fourong, pers. comm.). There have been discussions whether the piked dogfish in the east Atlantic belongs to one or several populations. Tagging experiments show that it most probably is only one population that migrates along the coasts seasonally (Aasen, 1964; Hjertnes, MS 1980; Gauld and MacDonald, MS 1982). In the beginning of the year they stay around the northern part of Scotland from where they move either south to the coast of Ireland or into the North Sea and the Skagerrak in late-summer (Hjertnes, MS 1980; Gauld and MacDonald, MS 1982). Tag recoveries from the Swedish coast are uncommon in the investigations. If this is because the fishing effort for piked dogfish was not very big at the time of the investigation or because the population here is small and therefore the probability of low tag recovery, can only be speculated here. It is also possible that tags recovered in the fishery were never returned.

That only one population exists in the West Atlantic has been demonstrated by tagging experiments (Templeman, 1976). It is known this population migrates seasonally. Here the sharks migrate north in the summer to feed outside Canada's coast and in autumn they migrate back to the northern East Coast of North America to give birth (Templeman, 1976). Transatlantic migration from east

\footnotetext{
${ }^{1}$ Masters' Thesis in Marine Zoology performed during the autumn of 1997, University of Gothenburg.
} 
to west has been shown through tagging experiments by Holden (1967) and from west to east by Templeman (1976), however, this is not a common occurrence.

Until they reach sexual maturity, the piked dogfish roam around divided into big shoals depending on fish size only. The youngest sharks swim near the surface, which is documented by food analyses (Jones and Geen, 1977c) and through fishing observations (Fourong, pers. comm.). The older the sharks become the deeper they stay (Wood et al., 1979). After sexual maturity the females and males segregate by sex, still in different length-classes. The females tend to stay in the mid-water and move to shallow water at the time of giving birth. In this period they do not feed. The males stay closer to the bottom and farther away from the coast (Hjertnes, MS 1980; Nammack et al., 1985). The reason for this behaviour is thought to be to reduce cannibalism. Since the smaller sharks swim close to the surface, they are not caught in traditional shark nets that usually are set $10 \mathrm{~m}$ off the sea floor. They are instead caught in pelagic nets fishing for Atlantic mackerel (Scomber scombrus) in late summer (Fourong, pers. comm.). Generally, the bigger females are caught in the shark nets and the males in the trawls fishing for shrimp (Fahy, MS 1988); in Sweden the main the species is the Norway lobster (Nephrops norvegicus).

\section{Sexual development}

Females. An immature female has small ovaries, non differentiated eggs and threadlike uteri. A sexually mature female has well-developed eggs in the ovaries and enlarged, highly vascularised uteri with the so-called candles (see Photo No. 1) or embryos present (da Silva and Ross, MS 1993). Earlier studies have shown that the females become sexually mature when they are between 11 and 12 years old in the Atlantic Ocean (Holden and Meadows, 1962; Nammack et al., 1985) and at an age of between 29 (Jones and Geen, 1977b) and 35 years in the Pacific Ocean (Saunders and McFarlane, 1993). It takes two years for the eggs to mature and the mature eggs measure 4-4.5 $\mathrm{cm}$ in diameter. Breeding takes place between December and February and the pups are born after approximately 23 months. For the first 4-6 months the fertilised eggs in each uterus are enclosed in an ambercoloured, gelatinous capsule candles. This capsule then ruptures and the embryos with a big yolk lie free in the females' uteri for 16-17 months before they are born in November-December (Photo No. 2 and 3). The pups are then on average $26-27 \mathrm{~cm}$ in total length. New eggs develop during the females' pregnancy, and one month after she has given birth she is ready to breed again (Ketchen, 1972; Jones and Geen, 1977b; Gauld, MS 1979).

Males. The males are considered immature if they have undeveloped claspers, small white threadlike gonads and straight spermiducts. Sexual maturity occurs at the age of 5-6 years for males in the Atlantic Ocean (Holden and Meadows, 1962; Nammack et al., 1985) and at the age of 16-19 years in the Pacific Ocean (Ketchen, 1975; Jones and Geen, 1977b). When they are sexually mature their claspers are big and rigid, the gonads are round and red and the spermiducts are tightly rolled (da Silva and Ross, MS 1993). It takes two years for the sperm to develop, but it seems as if they are able to mate every year since two different stages of the spermatogenesis separated through degenerated tissue are always present after sexual maturity (Jones and Geen, 1977b).

\section{Age determination}

Age analyses of elasmobranchs are generally difficult since their placoid scales and statoliths are useless for this purpose. Calcified yearly rings in the vertebrae of rays, skates and sharks (Holden and Vince, 1973; Stevens, 1975), x-ray spectrometry (Jones and Geen, 1977a) and

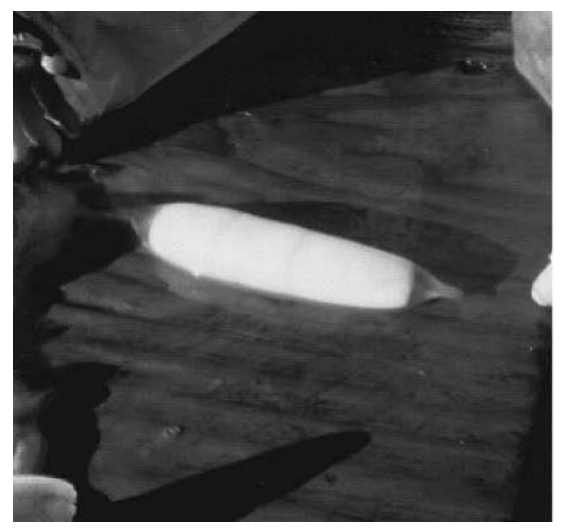

Photo No. 1. Candled eggs.

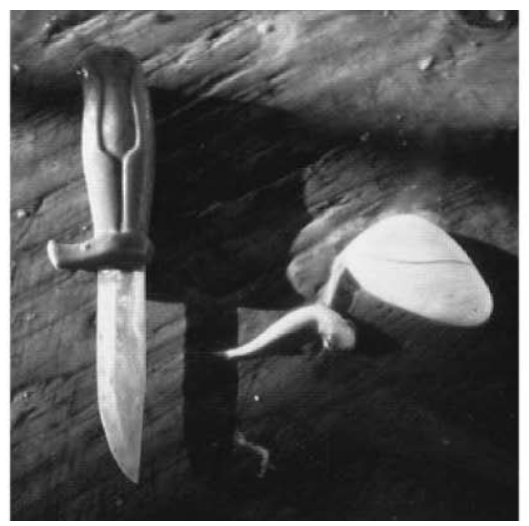

Photo No. 2. One-year-old embryo, about $7 \mathrm{~cm}$ total length.

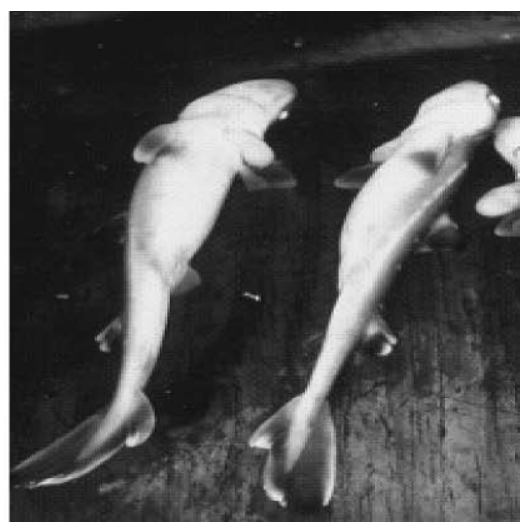

Photo No. 3. Two-year-old embryo, about $22 \mathrm{~cm}$ total length. 
length-frequency analysis (Holden, 1972) are some of the methods used in the efforts to age different elasmobranchs. All methods mentioned above are complicated and timeconsuming and some of them even useless. The piked dogfish belongs to one of the two shark families that have a spine in front of each dorsal fin. The spine in front of the first dorsal fin is shorter than the one in front of the second and therefore it is more difficult to read (Ketchen, 1975). The spine is like an enlarged placoid scale; that is, it is built up just like a tooth with pulp, dentine and enamel. It differs from ordinary teeth since it deposits pigment between the enamel and the dentine and it never stops growing. The spine is triangular in cross section and hollow. The growth of the spine is continuous over the year, but during the winter it grows slower. It seems like it is only the mantle that increases with the same speed over the year and therefore distinct rings are formed during periods of bad growth in the rest of the spine (Beamish and McFarlane, 1985). These rings often look like ridges on the spines and it is these dark ridges that are counted (see Photo No. 4).

Verification of annual ring formation has earlier been attempted by indirect methods like length-frequency analyses after von Bertalanffy (Holden and Meadows, 1962; Ketchen, 1975), the basal bands' monthly change in colour (Holden and Meadows, 1962), mercury accumulation and differences in length at known stages during the pregnancy and tagging experiments (Ketchen, 1975). After experiments with piked dogfish tagged with Petersen-discs - where they also had injected/bathed the sharks in oxytetracycline (OTC) and recovered the sharks more than two years later - they could state that it really is annual rings that one can count on the spines (Tucker, 1985; Beamish and McFarlane, 1985; McFarlane and Beamish, 1987). The broader light-coloured bands are formed during the summer, and the darker ridges are formed during the winter (Tucker, 1985).

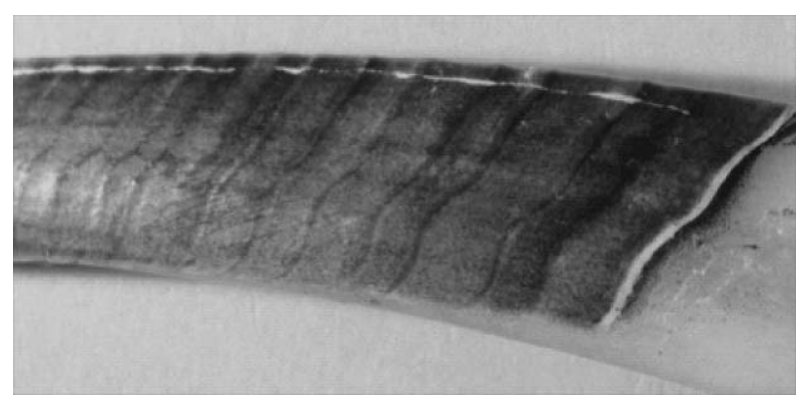

Photo No. 4. Distinct rings on a spine base.

\section{Materials and Methods}

The piked dogfish were caught on two occasions, 24 September 1997 and 29 October 1997, north of Väderöarna in the north-western archipelago of Sweden. The fisherman (Fourong, pers. comm.), who seasonally performs a directed fishery for piked dogfish, caught the sharks at depths ranging from 30 to $70 \mathrm{~m}$ in $10 \mathrm{~m}$ high shark nets (10 cm square mesh). The nets where examined and emptied after 24 hours in the water.

The spines in front of the second dorsal fin were removed. Apart from the recovered spines, the sharks' length, weight, sexual status and stomach content were examined. In the females, the numbers of larger eggs and embryos (if present) were counted and size estimated. The males' right claspers were measured from the tip to the edge of the ventral fins. The embryos and the adult sharks' lengths were measured in mm by moving the upper lobe of the tail down so that the snout and the tail were in a straight line (i.e. maximal length) and the weight was rounded off to the nearest hectogram.

The spines were dried and boiled to remove meat and skin (Polat and Gümüs, 1995). After drying the spines were kept in small, sealed plastic bags.

A Norwegian shrimp research expedition in the Skagerrak, 27-28 October 1997 provided 10 males and 1 female under $600 \mathrm{~mm}$ length. Dorsal spines from these 11 sharks were removed and aged.

\section{The age analyses}

The spines were illuminated from above and observed under 6 times magnification in a stereo microscope. All spines were read two times by the author, with two months between the occasions. The spine diameter of the base and the tip where it has just begun to get worn, from here on called the NWP (No Wear Point), were measured with $0.01 \mathrm{~mm}$ accuracy with vernier callipers (Ketchen, 1975). Photo No. 5 shows the difference between a worn and a non-worn spine.

A spine is considered to be worn when the diameter at the NWP is more than $2.05 \mathrm{~mm}$ (i.e. the calculated average diameter of the spine base one year after birth). The estimated age in spines with NWP $<2.05 \mathrm{~mm}(\mathrm{Y})$ were then plotted against the diameter of the spine base (X). A regression curve was then calculated. Then by inserting the value of the NWP from a worn spine on the curve, the number of rings that have been worn off was estimated. 


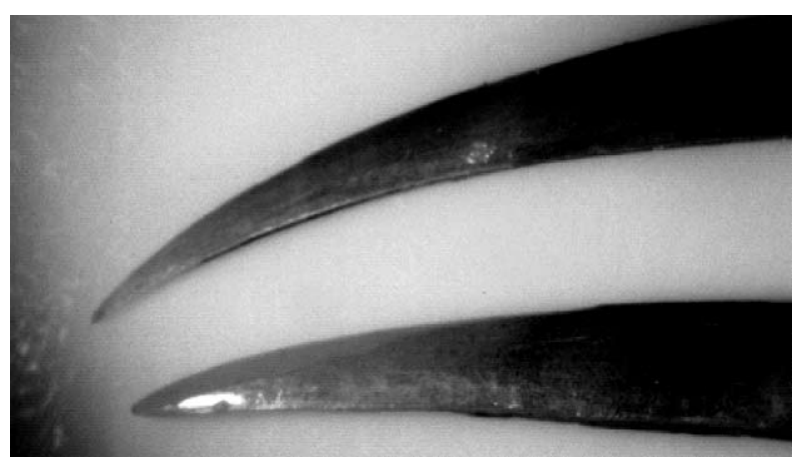

Photo No. 5. The difference between a non-worm (above) and a worm spine.

This estimated value plus the number of counted rings up to the NWP were taken to be the corrected age from birth. The spine is on average $1.55 \mathrm{~mm}$ at the base at birth and has two light-coloured bands that develop during its time as an embryo (Ketchen, 1975; Nammack et al., 1985), but these were not counted in this study.

\section{Sexual maturity}

Females without embryos were considered mature when their eggs were $2 \mathrm{~cm}$ or bigger. These females would have spawned next autumn and would have most probably already begun to slow down in growth, since they would be contributing to developing the big nutritious eggs. The males were classified as sexually mature when the spermiducts were tightly rolled and the claspers longer than the ventral fin.

\section{Growth}

Growth was calculated according to von Bertalanffy's (1938) formula:

$$
L_{t}=L_{\infty}\left(1-e^{-K\left(t-t_{0}\right)}\right)
$$

where $\quad L_{t}$ is length at the age $t$ (years)

$L_{\infty}$ is asymptotic length

$K$ is growth coefficient equal to zero

$t_{0}$ is age when the fish theoretical length is

\section{Results}

\section{Catch results}

On the first occasion 49 females and 7 males (24 September 1997) were examined and on the second occasion 64 females (no males) (29 October 1997). On both occasions the spine in front of the second dorsal fin was recovered for age analyses.
Age

Forty-one spines were considered to be unworn, that is - the diameters at NWP were less than $2.05 \mathrm{~mm}$. The estimated ages were plotted against the diameter of the base in a diagram, and since there were so few values they were also compared with Ketchen (1975) and Nammack et al. (1985) (see Fig. 1).

The equation of the curve is:

$$
\text { Age }=0.5735 \times \text { Diameter }^{6.7874}
$$

After this the values of NWP for the worn spines were put into the equation and the number of rings that had been worn off were calculated and the age corrected (see Fig. 2).

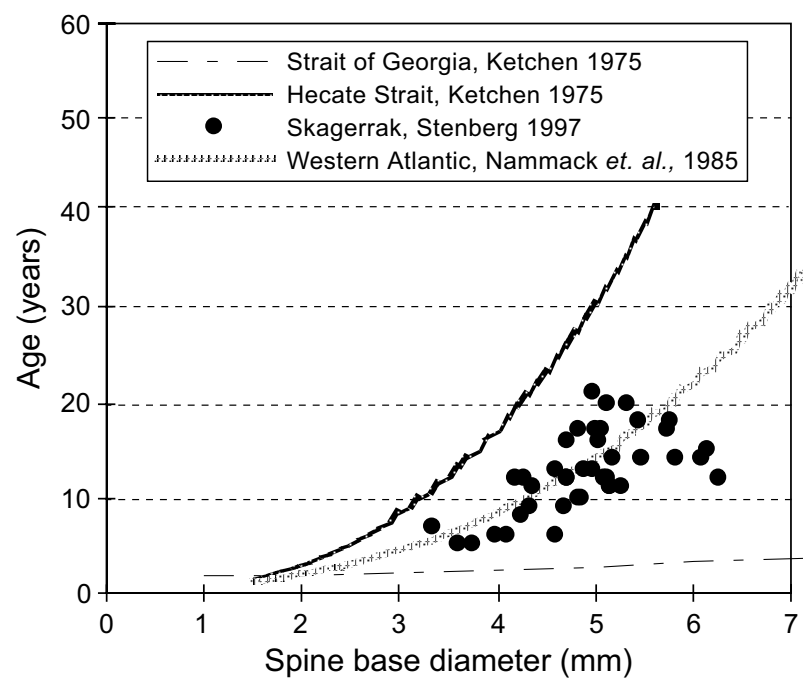

Fig. 1. Estimated age versus spine base diameter. Comparison between The Pacific Ocean (Ketchen, 1975), The Northwest Atlantic Ocean (Nammack, et. al., 1985) and at Stenberg in The Skagerrak (this study).

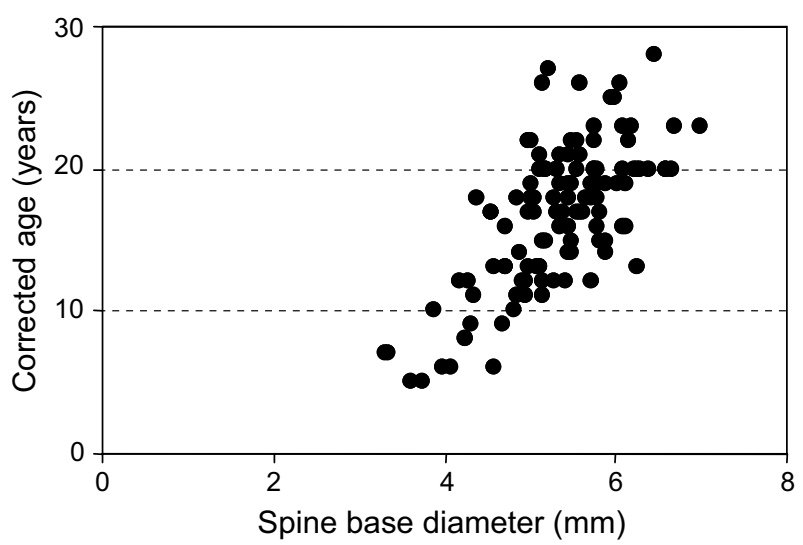

Fig. 2. The corrected age versus the diameter of the spine base. 
A $93 \mathrm{~cm}$ long female had the greatest number of rings. She had 23 rings and correction showed that she was 26 years old. The oldest female aged was 28 years old and $101 \mathrm{~cm}$ long.

\section{Growth}

The diameter of the spine base showed a correlation to the length of the shark (Fig. 3).

The growth calculated according to von Bertalanffy (1938) agrees with Nammack et al. (1985) results from 1985 (Fig. 4).

The largest shark in the study was a $107 \mathrm{~cm}$ female with an age of 23 years.

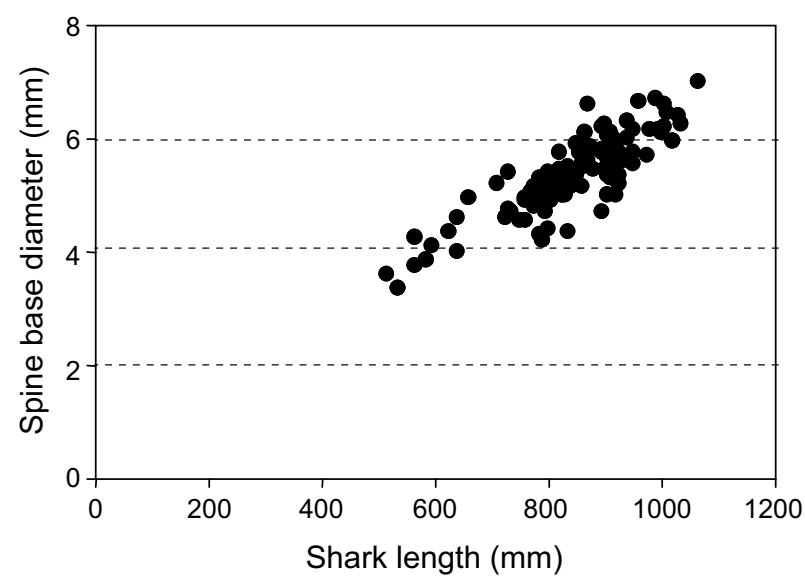

Fig. 3. Comparison between the diameter of the spine base and the length of the shark.

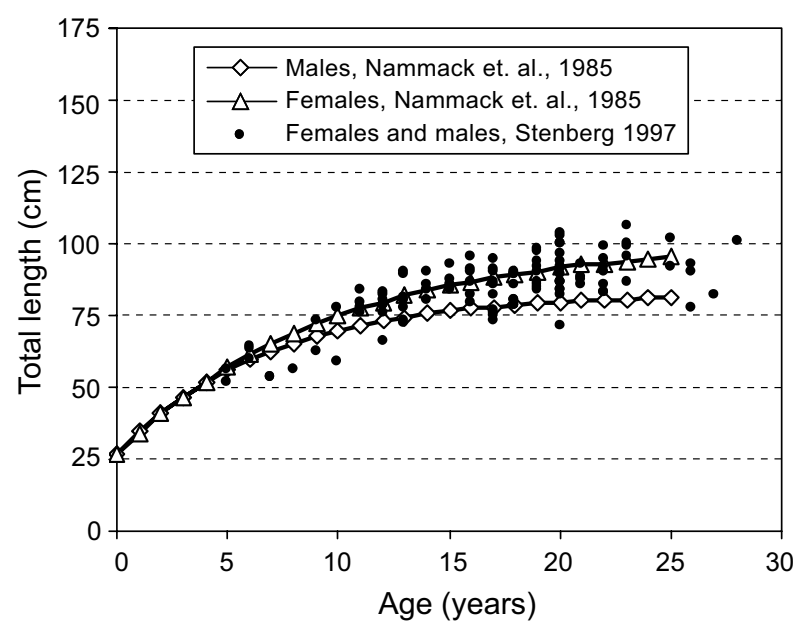

Fig. 4. Comparison of growth after von Bertalanffy between the Northwest Atlantic Ocean (Nammack et al., 1985) and at Stenberg in the Skagerrak (this study).

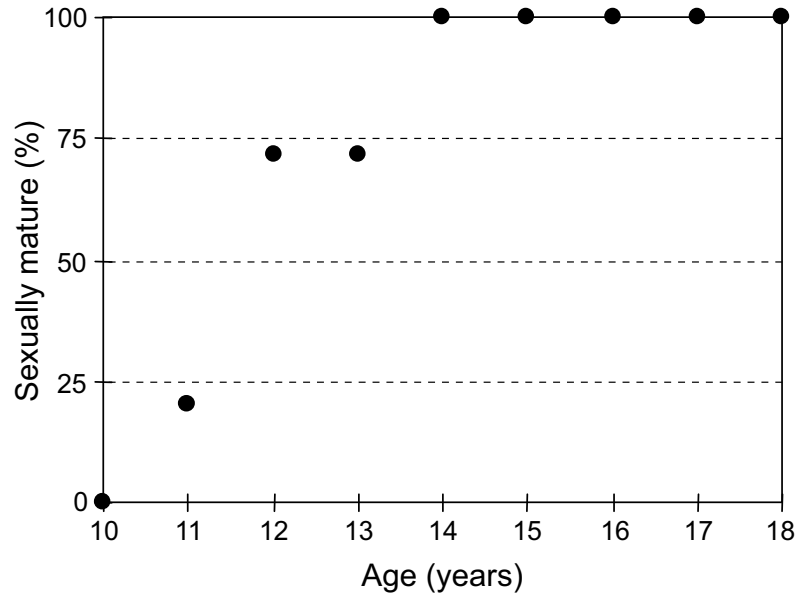

Fig. 5. Sexual maturity (\%) versus age of females.

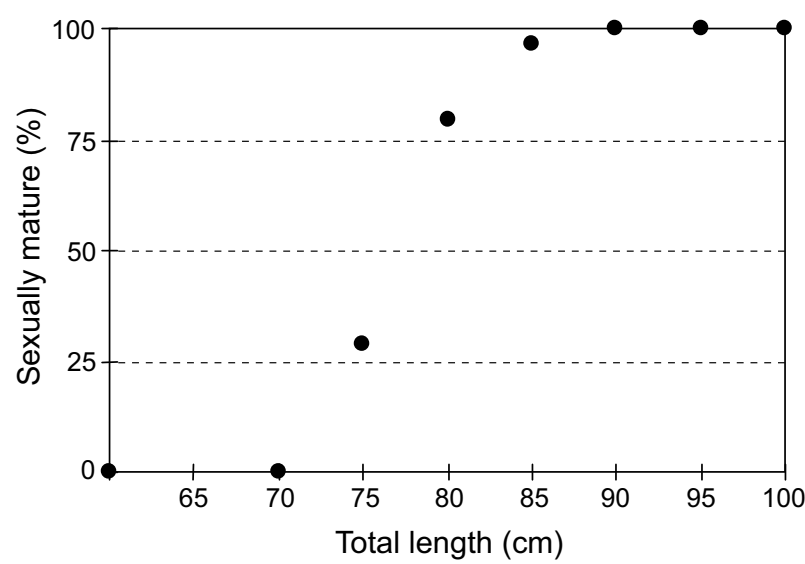

Fig. 6. Sexual maturity (\%) versus total length of females.

\section{Sexual maturity}

Of the 114 females that were investigated, 14 were not sexually mature (= empty uteri and egg less than $2 \mathrm{~cm}$ in diameter). At the age of 12-13 years and a length of $77 \mathrm{~cm} 50 \%$ of the females were sexually mature (Fig. 5 and 6). The largest immature female was $83 \mathrm{~cm}$ long and 11 years old and the smallest mature female was $73 \mathrm{~cm}$ long and 17 years old.

The largest immature male was $54 \mathrm{~cm}$.

\section{Fecundity}

The eggs were either 1.5-2 cm ("small eggs") or 4-4.5 cm ("big eggs") in diameter (one or two years old, respectively). The number of big eggs per female varied from 4 to 13, and the average number of big eggs was 8.08 (Table 1). Of the 23 females that only contained big eggs, 4 had eggs between 2 and $3 \mathrm{~cm}$ in size. 
TABLE 1. Number of females with large eggs $(>2 \mathrm{~cm})$ in the ovaries, distribution relationship of the length of the female and the number of eggs.

\begin{tabular}{|c|c|c|c|c|c|c|c|c|c|c|c|}
\hline \multirow{2}{*}{$\begin{array}{l}\text { Total length } \\
\text { females }(\mathrm{cm})\end{array}$} & \multicolumn{10}{|c|}{ No. of females with 4 to 13 large eggs in the ovaries } & \multirow{2}{*}{$\begin{array}{c}\text { Average number eggs/ } \\
\text { female (SD) }\end{array}$} \\
\hline & 4 & 5 & 6 & 7 & 8 & 9 & 10 & 11 & 12 & $\overline{13}$ & \\
\hline $70-74$ & & & & 1 & & & & & & & 7.00 \\
\hline $75-79$ & 1 & 2 & 4 & 3 & 2 & & & & & & $6.25(1.22)$ \\
\hline $80-84$ & & 3 & 2 & 7 & 1 & 3 & & & & & $6.94(1.34)$ \\
\hline $85-89$ & & 1 & 5 & 10 & 4 & 1 & 3 & 2 & & & $7.62(1.63)$ \\
\hline $90-94$ & & 1 & 3 & 3 & 5 & 2 & 3 & 5 & 1 & & $8.65(2.01)$ \\
\hline 95-99 & & & 1 & & & & 3 & 2 & 1 & & $10.00(1.91)$ \\
\hline $100-104$ & & & & & 1 & & & 4 & 1 & 1 & $11.00(1.53)$ \\
\hline 105-109 & & & & & & & & & 1 & & $12.00 \quad(0)$ \\
\hline Total & 1 & 7 & 15 & 24 & 13 & 6 & 9 & 13 & 4 & 1 & $8.08 \quad(2.15)$ \\
\hline
\end{tabular}

TABLE 2. Number of females with "one and two years old" embryos in uterus, distribution relationship of the females' length and the number of embryos.

\begin{tabular}{|c|c|c|c|c|c|c|c|c|c|c|c|c|c|c|}
\hline \multirow{2}{*}{$\begin{array}{l}\text { Total length } \\
\text { females }(\mathrm{cm})\end{array}$} & \multicolumn{13}{|c|}{ Number of females with 1 to 13 free embryos in the uterus } & \multirow{2}{*}{$\begin{array}{c}\text { Average number } \\
\text { embryos/females (SD) }\end{array}$} \\
\hline & 1 & 2 & 3 & 4 & 5 & 6 & 7 & 8 & 9 & 10 & 11 & 12 & 13 & \\
\hline $70-74$ & & & & & & 1 & & & & & & & & 6.00 \\
\hline 75-79 & 1 & & 2 & 3 & 1 & 1 & & & & & & & & $3.75(1.49)$ \\
\hline $80-84$ & 1 & 1 & 1 & 4 & 3 & 4 & & & 1 & & & & & $4.67(1.91)$ \\
\hline $85-89$ & 1 & 1 & & 1 & 8 & 5 & 2 & & & & & & & $5.06(1.51)$ \\
\hline $90-94$ & & & 1 & 2 & 3 & 3 & 4 & 4 & & & 1 & & & $6.39(1.91)$ \\
\hline 95-99 & & & & 1 & 1 & 1 & 2 & 1 & 3 & & & & & $7.11(1.83)$ \\
\hline $100-104$ & & & & & 1 & & & 2 & 1 & 2 & & & 1 & $9.00(2.45)$ \\
\hline 105-109 & & & & & & & & 1 & & & & & & $8.00 \quad(0)$ \\
\hline Total & 3 & 2 & 4 & 11 & 17 & 15 & 8 & 8 & 5 & 2 & 1 & & 1 & $5.80(2.27)$ \\
\hline
\end{tabular}

The number of embryos varied between 1 and 13 per female (Table 2). Of the 77 females with embryos in uteri, 39 were due to deliver during the same season of capture. The one-year-old embryos were around $7 \mathrm{~cm}$ long during the first occasion in late September 1997 and they had external gills. One month later they were between 9 and $11 \mathrm{~cm}$ in length with internal gills. Their yolk sacks at both occasions were about $6 \mathrm{~cm}$ in diameter. The embryos that would be born this season (most likely between November and January) were between 18 and $25 \mathrm{~cm}$ in length. During the first occasion of investigation these embryos had external yolk sacks that were less than $1 \mathrm{~cm}$ in diameter. In the second occasion in October, the yolks had in most cases been fully absorbed and only a non-healed slit could be seen on the abdomen.

Two females contained candles in October. One of these had 10 eggs that were $2 \mathrm{~cm}$ in diameter and one embryo that was $11 \mathrm{~cm}$ long. Consequently, it seems like the fertilized eggs (in the candle) had not wandered into the uteri, but they had not been resorbed or pushed out either.

\section{Discussion}

To be able to give a fairly true picture of a population, representative sampling is needed. This is particularly difficult with the piked dogfish since they divide into different shoals depending on size and sex. On both occasions, the fish caught were mostly females between 70 and $100 \mathrm{~cm}$ in length, and therefore the sample was not representative for the whole population.

\section{Age analyses}

Since the spine constantly grows and the earliest rings are worn off, if in age analyses one does not compensate for this the age is underestimated and the growth rate overestimated (Holden and Meadows, 1962; Ketchen, 1975). Ketchen (1975) modified and simplified Holden and Meadows (1962) method to estimate the number of 
rings that have been worn off, and therefore Ketchen's method was used in this study. Holden and Meadows (1962) described in detail different types of rings and characterized many rings as false. This could have led them to underestimate the age of the piked dogfish. After conducting age readings on the spines in this study, I am willing to agree with Ketchen (1975): the rings show so much of individual variation regarding colour, width and the appearance in general, that to decide special criteria for a ring's validity is impossible. Consequently, all rings that were fairly distinct have been counted in this study as true annual ring. This procedure may have led to an overestimation of the age, but since the growth in the piked dogfish is slow and non-continuous, which Holden and Meadows did not assume (Ketchen, 1975), it seems logical to follow Ketchen's procedure. (Ketchen (1975) in his paper gives several examples of tagging investigations where the sharks at the time of recapture showed zero growth or even a decrease in length.

In this study, I read the spines. The interpretation error has therefore not been estimated. In earlier studies one to three people have read the spines and in many cases they also read the spines several times to get a more certain picture. The following are reviews of: one person reading the spines (Soldat, 1982; Beamish and McFarlane, 1985; Tucker, 1985), two persons (Holden and Meadows, 1962; Ketchen, 1975; Nammack et al., 1985 (2 times); Fahy, MS 1988; Saunders and McFarlane, 1993; Polat and Gümüs, 1995), three persons (McFarlane and Beamish, 1987). They compared the results among the different readings to find agreement, and rejected spines where the age had been disagreeing by more than two years. In this study it has not been possible to compare the two readings since they were done in different ways. In the first time all rings were counted, including those that could be seen where the spine was worn off, in the second time all rings until the NWP were counted and after measuring the diameter at NWP, the number of rings worn off was estimated.

The results from this study correlate well with those of Nammack et al. (1985) (see Fig. 1).

\section{Growth}

It has been mentioned several times that the growth of the piked dogfish is slow. Little is known about the growth of dogfish in the first years after birth, since they generally are absent in the commercial fishing catches, but general indications are that the growth until sexual maturity is faster. After sexual maturity growth is only about one $\mathrm{cm}$ a year, and there are examples of zero growth or even shrinkage (Ketchen, 1975).

\section{Sexual maturity}

Most authors consider it difficult to decide when a female piked dogfish is sexually mature, if there are no eggs present. Since it takes two years for the eggs to develop to a mature size (ca $4.5 \mathrm{~cm}$ ), they are around $1.5-2 \mathrm{~cm}$ in diameter after one year. The question is then whether one should consider the female sexually mature when she is ready to spawn for the first time or one year earlier when the eggs are developing. In earlier studies the authors have considered the females sexually mature by different sizes of the eggs: $1.5 \mathrm{~cm}$ (Nammack et al., 1985; da Silva and Ross, MS 1993), $2 \mathrm{~cm}$ (Saunders and McFarlane, 1993), $2.5 \mathrm{~cm}$ (Ketchen, 1972), 3-4 cm (Fahy, MS 1988; Gauld, MS 1979), "large eggs" - $4 \mathrm{~cm}$ mature (Jones and Geen, 1977b), $-4.5 \mathrm{~cm}$ (Kirnosova, 1989), "large eggs" (Holden and Meadows, 1962; 1964).

TABLE 3. Records of the age at which $50 \%$ of the population is sexually mature.

\begin{tabular}{lccc}
\hline \hline & & \multicolumn{2}{c}{$50 \%$ Sexually Mature } \\
\cline { 2 - 4 } Study & Area & & \\
\hline & The Atlantic Ocean & & \\
Holden and Meadows, 1964 & The North Sea & 11 & 5 \\
Nammack et al., 1985 & The Northwest Atlantic & 12 & 6 \\
This study, 1997 & The Skagerrak & $12-13$ & \\
& The Pacific Ocean & & \\
Ketchen, 1975 & Hecate Strait & 34 & 17 \\
Ketchen, 1975 & Strait of Georgia & 31 & 16 \\
Jones and Geen, 1977b & Strait of Georgia & 29 & 19 \\
McFarlane and Beamish, 1987 & Strait of Georgia & 35 & \\
Saunders and McFarlane, 1993 & British Columbia & 35.5 & \\
& The Black Sea & & \\
Kirnosova, 1989 & The Black Sea & $10-15$ & $9-13$ \\
\hline
\end{tabular}


TABLE 4. Comparison between different studies of the number of mature eggs per female divided into different length-classes.

\begin{tabular}{|c|c|c|c|c|c|c|}
\hline \multirow[b]{2}{*}{ Study } & \multirow[b]{2}{*}{ Area } & \multicolumn{4}{|c|}{ Length female $(\mathrm{cm})$} & \multirow[b]{2}{*}{ Average } \\
\hline & & $70-79$ & $80-89$ & $90-99$ & $100-109$ & \\
\hline \multicolumn{7}{|c|}{ The Atlantic Ocean } \\
\hline Holden and Meadows, 1964 & The North Sea & 3.5 & 5.2 & 7.4 & 10.2 & 6.6 \\
\hline Gauld, MS 1979 & The North Sea & 5.4 & 7.8 & 9.9 & 12.5 & 8.9 \\
\hline Nammack et. al., 1985 & The Northwest Atlantic & 4.0 & 5.4 & 7.8 & 10.3 & 7.8 \\
\hline Fahy, MS 1989 & The North Sea & & 6.1 & 8.1 & 10.1 & 8.1 \\
\hline This study, 1997 & The Skagerrak & 6.6 & 7.3 & 9.3 & 11.5 & 8.1 \\
\hline \multicolumn{7}{|c|}{ The Pacific Ocean } \\
\hline Ketchen, 1972 & The Northeastern Pacif & & & & 6.8 & \\
\hline \multicolumn{7}{|c|}{ The Black Sea } \\
\hline Kirnosova, 1989 & The Black Sea & & & & & 22 \\
\hline
\end{tabular}

TABLE 5. Comparison between different studies of the number of embryos per female divided into different length-classes.

\begin{tabular}{|c|c|c|c|c|c|c|}
\hline \multirow[b]{2}{*}{ Study } & \multirow[b]{2}{*}{ Area } & \multicolumn{4}{|c|}{ Length female $(\mathrm{cm})$} & \multirow[b]{2}{*}{ Average } \\
\hline & & $70-79$ & $80-89$ & $90-99$ & $100-109$ & \\
\hline \multicolumn{7}{|c|}{ The Atlantic Ocean } \\
\hline Holden and Meadows, 1964 & The North Sea & 3.4 & 4.8 & 6.6 & 8.7 & 5.8 \\
\hline Gauld, 1979 & The North Sea & 1.9 & 5.4 & 8.8 & 12.2 & 7.1 \\
\hline Nammack et. al., 1985 & The Northwest Atlantic & & 3.9 & 6.2 & 8.6 & 6.6 \\
\hline Fahy, 1989 & The North Sea & & 4.6 & 6.0 & 7.3 & 6.0 \\
\hline This study, 1997 & The Skagerrak & 4.9 & 4.9 & 6.8 & 8.5 & 5.8 \\
\hline \multicolumn{7}{|c|}{ The Pacific Ocean } \\
\hline Ketchen, 1972 & The Northeastern Pacific Ocean & & 3.8 & 5.8 & 7.8 & $6.6^{1}$ \\
\hline \multicolumn{7}{|c|}{ The Black Sea } \\
\hline Kirnosova, 1989 & The Black Sea & & & 7.4 & 10.1 & $14^{1}$ \\
\hline
\end{tabular}

The estimated age of $50 \%$ sexual maturity in this study is similar to the results from other studies from the Atlantic (Table 3).

\section{Fecundity}

Fecundity can be calculated in three different ways, viz. by counting; 1) ovarian eggs (Table 4), 2) fertilized eggs - the so called candles, and 3) the embryos in uterus (Table 5). The ovarian eggs can be bad or sterile and therefore some eggs are often resorbed or expelled - comparing between the average number of eggs and embryos show that the number of eggs is always bigger (compare Tables 4 and 5).

It is important that the parent is of average size for the population when population estimations are made from the number of embryos since the number of embryos partly depends on the size of the female (Ketchen, 1972). The size of the embryo at the time for delivery is partly dependant on the size of the mother as well. Embryos, especially those which are nearly fully developed, are also aborted rather easily from the female during capture. Therefore, 
when there are only one or two embryos in a female it may mean that some may have been aborted during the fishing activity. The most reliable way to estimate fecundity, according to Fahy (MS 1989), would therefore be to count the fertilised eggs (in the candles). This situation occurs mainly during springtime (during the investigations in the autumn only two females contained candles) and that is the period when the piked dogfish disappears from the Swedish coast.

The number of large eggs in this study was on the high side compared with other studies from the Atlantic Ocean (see Table 4). The average number of embryos in this study was on the low side (see Table 5). The low number of embryos in this study could be a result of abortion of embryos during capture. However, the differences in the number of embryos between the studies performed in the Atlantic Ocean are not large. In the Pacific Ocean and in the Black Sea the piked dogfish becomes sexually mature at a bigger size than in the Atlantic Ocean, and the females can reach maximum total lengths of 130 and 145 $\mathrm{cm}$, respectively. This leads to a higher average number of embryos in the female sharks from these areas than in the females from the Atlantic Ocean.

\section{Conservation}

Many of the studies mentioned have been performed to investigate if the piked dogfish is a threatened species or if it is possible to exploit it even more. Holden and Meadows (1964) stated in their study that the reproductive potential of the piked dogfish was below the level at which they would be able to replace the population under prevailing fishing pressure. Also Aasen (1964) warned that the current fishing pressure was too high for the population of piked dogfish, and this led to the introduction of a minimum fishing size of $70 \mathrm{~cm}$ for piked dogfish in Norway. Gauld (MS 1979) thought that Holden and Meadows (1964) were wrong and stated that the piked dogfish can compensate for the fishing by an increase in fecundity, but of course only up to a certain level. Hjertnes (MS 1980) demanded intensified research and believes in a regulation of the fishing for the piked dogfish through international catch quotas and protection of the older (= larger) females. Nammack et al. (1985) warned of over exploitation of females when minimum sizes are introduced and therefore suggested catch quotas by sex but also a change in the demand from the market; that is, a bigger demand for smaller sharks.

The fishing pressure in Sweden is relatively small; 214 tons were landed in 1997 and approximately half of the catch came from artisanal fisheries seasonally targeting piked dogfish.

\section{Future Studies}

It is often said that the piked dogfish is a species that migrates frequently and over great distances. But no tagging experiments have been performed along the Swedish west coast and only a few individuals that have been tagged in the North Sea and outside the Norwegian coast have been recaptured here (Aasen, 1964; Hjertnes, MS 1980; Gauld, 1982; Gauld and MacDonald, MS 1982; Tucker, 1985). Where do the "Swedish" piked dogfish go when they disappear from the Swedish coast in December? Do they swim to other areas and get caught there or do they gather themselves in non-fishing depths, in for example Kosterrännan, as the Swedish fishermen believe (Fourong, pers. comm.). Popup tags, which combine data logging and satellite transmission, could help answer these questions.

\section{Acknowledgement}

Many thanks to Johan Fourong and Olof, Bengt Sjöstrand, Lars Stenberg, Susanne Tärnlund and the employees of Institute for Coastal Research (the Gothenburg office).

\section{References}

AASEN, O. 1964. The exploitation of the spiny dogfish (Squalus acanthias L.) in European waters. Fisk. Dir. Skr. Ser. Havunders., 13(7): 5-16.

BEAMISH, R. J., and G. A. MCFARLANE. 1985. Annulus development on the second dorsal spine of the dogfish (Squalus acanthias) and its validity for age determination. Can. J. Fish. Aquat. Sci., 42(11): 1799-1805.

FAHY, E. MS 1988. Recent developments in the Irish fisheries, Squalus acanthias (L.). ICES C.M. Doc., No. 1988/H:6.

MS 1989. The value of alterations in fecundity to an exploited shark population, illustrated by Squalus acanthias (L.). ICES C.M. Doc., 1989/Mini No:2.

GAULD, J. A. MS 1979. Reproduction and fecundity of the Scottish-Norwegian stock of spurdogs, Squalus acanthias (L.). ICES C.M. Doc., No. 1979/H:54.

1982. The dogfish - an ocean rover. Scottish Fish. Bull., 47: 13-16.

GAULD, J. A., and W. S. MACDONALD. MS 1982. The results of tagging experiments on spurdogs Squalus acanthias L. around Scotland. ICES C.M. Doc., 1982/No. H:51.

HJERTNES, P. O. MS 1980. The spurdog in the North Sea area; the Norwegian fishery and observations on changes in migration pattern. ICES.C.M. Doc., No. 1980/H:60.

HOLDEN, M. J. 1967. Transatlantic movement of a tagged spurdogfish. Nature, 214(5093, 99): 1140-1141.

1972. The growth rates of Raja brachiura, $R$. clavata and $R$. montagui as determined from tagging data. J. Cons. Int. Explor. Mer., 34(2): 161-168.

HOLDEN, M. J., and P. S. MEADOWS. 1962. The structure of the spine of the spur dogfish (Squalus acanthias L.) and its use for age determination. J. Mar. Biol. Assoc. U.K.., 

42: 179-197.
1964. The fecundity of the spurdog (Squalus acanthias L.). ICES J. Cons., 28: 418-424.

HOLDEN, M. J., and M. R. VINCE. 1973. Age vaidation studies on the centra of Raja clavata using tetracycline. ICES J. Cons., 35(1): 13-17.

JONES, B. C., and G. H. GEEN. 1976. Taxonomic reevaluation of the spiny dogfish (Squalus acanthias L.) in the northeastern Pacific ocean. J. Fish. Res. Board Can., 33(11): 2500-2506.

1977a. Age determination of an elasmobranch (Squalus acanthias) by x-ray spectrometry. J. Fish. Res. Board Can., 34(1): 44-48.

1977b. Reproduction and embryonic development of spiny dogfish (Squalus acanthias) in the Strait of Georgia, British Columbia. J. Fish. Res. Board Can., 34(9): 1286-1292.

1977c. Food and feeding of spiny dogfish (Squalus acanthias) in British Columbia waters. J. Fish. Res. Board Can., 34(11): 2067-2078.

KETCHEN, K. S. 1972. Size at maturity, fecundity, and embryonic growth of the spiny dogfish (Squalus acanthias) in British Columbia waters. J. Fish. Res. Board Can., 29(12): 1717-1723.

1975. Age and growth of dogfish Squalus acanthias in British Columbia waters. J. Fish. Res. Board Can., 32(1): 43-59.

KIRNOSOVA, I. P. 1989. Reproduction of spiny dogfish, Squalus acanthias, in the Black Sea. J. Ichthyol., 29(3): 21-26.

MCFARLANE, G. A., and R. J. BEAMISH. 1987. Validation of the dorsal spine method of age determination for spiny dogfish. In: Age and Growth of Fish. R. C. Summerfelt and G. E. Hall (eds.), p. 287-300.

NAMMACK, M. F., J. A. MUSICK, and J. A. COLVOCORESSES. 1985. Life history of spiny dogfish off the Northeastern United States. Trans. Amer. Fish. Soc., 114(3): 367-376.

POLAT, N., and A. K. GÜMÜS. 1995. Age determination of spiny dogfish (Squalus acanthias L. 1758) in Black Sea waters. Isr. J. Aquacult. Bamidgeh., 47(1): 17-24.

SAUNDERS, M. W., and G. A. MCFARLANE. 1993. Age and length at maturity of the female spiny dogfish, Squalus acanthias, in the Strait of Georgia, British Columbia, Canada. Environ. Biol. Fish, 38(1-3): 49-57.

DA SILVA, H. M., and M. R. ROSS. 1993. Reproductive strategies of spiny dogfish, Squalus acanthias, in the NW Atlantic. ICES C. M. Doc., No. 1993/G:51.

SOLDAT, V. T. 1982. Age and size of spiny dogfish, Squalus acanthias, in the Northwest Atlantic. NAFO Sci. Coun. Studies, 3: 47-52.

STEVENS, J. D. 1975. Vertebral rings as a means of age determination in the blue shark (Prionace glauca L.). J. Mar. Biol. Assoc. U.K., 55: 657-665.

TEMPLEMAN, W. 1976. Transatlantic migrations of spiny dogfish (Squalus acanthias). J. Fish. Res. Board Can., 33(11): 2605-2609 notes.

TUCKER, R. 1985. Age validation studies on the spines of the spurdog (Squalus acanthias) using tetracycline. J. Mar. Biol. Assoc. U.K., 65(3): 641-651.

VON BERTALANFFY, L. 1938 .A quantitative theory of organic growth (inquiries on growth laws II). Hum. Biol., 10: $181-213$.

WOOD, C. C., K. S. KETCHEN, and R. J. BEAMISH. 1979. Population dynamics of spiny dogfish (Squalus acanthias) in British Columbia waters. J. Fish. Res. Board Can., 36(6): 647-656. 